\title{
KRIMINALITETSUDVIKLINGEN I ISLAND \\ - TENDENSER OG FORKLARINGER
}

\author{
Af Professor, Ph. D. Helgi Gunnlaugsson
}

Unlike many other nations in the industrialized West, Iceland until the last decade or so compiled only sketchy information on police, court, and prison activities. This sorry state of affairs has made it difficult for Iceland to be included in international comparisons on crime. According to the admittedly scanty records available, the crime rate for serious offences such as homicide, robbery and aggravated assault remains lower in Iceland than in most Western nations. While intermittent, local crime statistics clearly indicate that substance abuse is a dominant, long-term focus of Icelandic law enforcement, as reflected in rates of driving while intoxicated, public drunkenness and, more recently, drug violations. On the heels of profound societal change in the latter part of the $20^{\text {th }}$ century, more systematic records of crime made available by local authorities indicate that crime has increased, and population surveys suggest that citizen concern has deepened. With the establishment of the National Commissioner of the Icelandic Police in 1997, crime data has been gathered nationally, which will help to facilitate international comparisons on crimes known to the police in the future. As for crime types, the number of cases involving drug violations and sex crimes have increased the most in the past few years while rates of other forms of crime have stabilized."

Kriminologiske undersøgelser har ikke nogen lang historie i Island og er heller ikke særlig talrige, hvilket har forskellige grunde. Sociale videnskaber er endnu et ganske ungt fag i Island, som i det mindste delvis forklarer, hvorfor vi ikke har udført flere unders $\emptyset$ gelser i kriminologi. Der er imidlertid en anden og mere nærliggende grund til de relativt få undersøgelser. Registrering og opbevaring af offentlige oplysninger om forbrydelser har til for nylig ikke været videre målrettet. Forvaringsdomme blev op igennem det 20. århundrede offentliggjort med meget uregelmæssige intervaller og er ikke blevet udgivet i de seneste år. Den islandske højesteret offentligg ør alle domme på sit websted men herredsdomstolene i mindre udstrækning. Oplysninger fra statsadvokaten om antallet af anklager er endnu ikke blevet offentliggjort og har således ikke været tilgængelige for undersøgel-

\footnotetext{
'Title in English: Crime in Iceland: Trends and Explanations. Original in Danish.
} 
ser. Anmeldelser til politiet er ikke blevet systematisk arkiveret før på de allerseneste år. Alle disse faktorer angående tilgængeligheden af offentlige oplysninger om forbrydelser har i høj grad vanskeliggjort undersøgelser af kriminalitetshyppigheden i Island og i endnu højere grad sammenligningen med andre lande. Faktisk har det fra islandsk side været meget vanskeligt på en overbevisende måde at besvare det påtrængende spørgsmål om forbrydelser er flere eller færre i Island end i vore nabolande, skønt vi har været i stand til at give visse fingerpeg.

\section{Offentlige oplysninger om forbrydelser i Island}

Mange ting peger nu på, at registreringen af offentlige oplysninger efterhånden er blevet mere målrettet. En samlet registrering af alle politirapporter for landet som helhed påbegyndtes i 1997 ved etableringen af Islands rigspolitichefembede, hvorefter det har været muligt at indhente oplysninger om forbrydelsers hyppighed i hele landet. Fra 1977 til 1997 eller i 20 år var institutionen Rigskriminalpolitiet aktiv og havde et arbejdsdistrikt, der strakte sig over hele hovedstadsområdet. Institutionen udgav fra 1991 årsrapporter, der dækkede perioden 1988-1996 og giver et indblik i det offentlige billede af forbrydelser i det distrikt, hvor trods alt næsten to tredjedele af Islands befolkning bor (Helgi Gunnlaugsson, 2000). Oplysninger om anmeldte forbrydelser for hele Island er imidlertid ikke tilgængelige før fra 1998. Islands Fængselsvæsen blev grundlagt i 1989, og denne institution har bevaret nøjagtige rapporter om sin aktivitet, f. eks. hvad angår antallet af fanger, grunde til fængslinger og forvaringsdommenes længde. Offentlig registrering og tilgængeligheden af oplysninger om forbrydelser i Island er således blevet bedre i de seneste år, skønt situationen endnu ikke er sammenlignelig med hvad man kender hos de fleste andre vestlige nationer, men udviklingen går tydeligvis i den rigtige retning.

Hvorfor har den offentlige registrering af forbrydelser været så forsømt alle disse år? Og er det samme tilfældet med alle offentlige oplysninger i Island? Slet ikke. Inden for mange andre sektorer har man i mange årtier systematisk registreret oplysninger, f. eks. om vejret og om fiskefangst. En sandsynlig forklaring på forsømmelsen er, at forbrydelser og de dermed forbundne anliggender længe har været lidet yndede emner som man ikke synes fortjente nogen nærmere unders $\emptyset$ gelse eller registrering. Forbrydelser ansås jo ikke for at være noget stort problem i Island, og myndighederne eller andre i samfundet fremsatte derfor ikke noget klart krav om udbedringer i denne emneområde. Men så længe oplysninger om forbrydelsers hyppighed og karakter er få og vanskeligt tilgængelige, forstærker dette netop den opfattelse at forbrydelser ikke er noget problem i samfundet.

Skønt registreringen i de seneste år er blevet mere målrettet og grundlaget for sammenligning med andre lander derigennem mere solidt, må sådanne sammenligninger mellem forskellige lande altid foretages med visse forbehold. Sam- 
tidig med at specialisering og professionalisme i stigende grad kendetegner retshåndhævelsessystemets parter og tilgængeligheden af oplysninger om forbrydelser er blevet bedre, er debatten om forbrydelser og tilknyttede problemer blevet tydeligere. Bekymringer på grund af forbrydelser har blandt andet vist sig i form af taler og forespørgsler i Islands Alting, der i de seneste år i voksende omfang har efterlyst analyser af emner med tilknytning til forbrydelser, f. eks. af voldtægt, vold i hjemmet, unge voldsforbryderes stilling eller udviklingen i narkoverdenen. Sådanne forespørgsler viser også tingets vilje til at foretage udbedringer i forhold der vedrører forbrydelser.

\section{Forbrydelser i Island set i internationalt lys}

Hvordan står Island så i sammenligning med andre nationer vedrørende forbrydelser, og hvordan har udviklingen været? Som før nævnt er det på mange områder vanskeligt at besvare dette spørgsmål overbevisende på grund af manglende oplysninger. Dog kan man med stor sikkerhed påstå, at hyppigheden af alvorlige forbrydelser i Island i sammenligning med andre vestlige lande, heriblandt også de skandinaviske lande, har været lav. Flere eksempler fra tidligere tider viser denne kendsgerning. I perioden 1881 til 1925 blev f. eks. ingen i Island dømt for mord. De islandske myndigheder anklagede dog i perioden 1977 til 1994 gennemsnitligt 1,5 til 1,7 personer for mord hvert år (Gunnlaugsson og Galliher, 2000).

Nyere undersøgelser viser også, at antallet af straffedomme generelt er steget drastisk i perioden 1881 til 1977, selv set i forhold til befolkningens størrelse på ethvert tidspunkt. Tilsyneladende har der været en betydelig stigning i antallet af forbrydelser i Island i det 20. århundrede, skønt sådanne resultater altid bør tages med forbehold, idet kun en del af de begåede forbrydelser får politiets og domstolenes opmærksomhed. Forskellig prioritering, arbejdsmetoder og retshåndhævelsens omfang har alt indflydelse på hyppigheden af registrerede forbrydelser og kan forvrænge resultaterne betydeligt. Netop derfor kan den øgede vægt på retshåndhævelse og ligeledes $\emptyset$ get professionalisme inden for retssystemet nu i de seneste år spille en stor rolle i den øgede hyppighed af registrerede forbrydelser i samfundet.

I en sammenlignende undersøgelse baseret på oplysninger fra Interpol fra 1993 viste det sig, at mordhyppigheden i Reykjavik (0,9 pr. 100.000 indbyggere) var to til fem gange mindre end i de andre nordiske hovedstæder (det islandske statsministerium, 1996). Samme undersøgelse taler for, at hyppigheden af grove overfald, tyverier og narkotikaforbrydelse i Reykjavik kun har være en ganske lav procentdel af hyppigheden i de andre hovedstæder. Røverier har ligeledes været sjældne, og det kan nævnes, at der i perioden 1987-1994 gennemsnitligt blev anmeldt 17 røverier pr. år i Reykjavik (ca. 17 pr. 100.000 indbyggere), hvil- 
ket er en betydelig lavere hyppighed end i Nordens andre hovedstæder, selv når der tages hensyn til befolkningsantallet. Sluttelig kan det nævnes, at antallet af fængslede i Island er blandt de laveste der kendes i de vestlige lande, eller ca. 35 pr. 100.000 indbyggere i slutningen af 1998 (Gunnlaugsson og Galliher, 2000). Antallet af fængslede pr. 100.000 indbyggere $\mathrm{i}$ andre nordiske lande er helt op til dobbelt så mange, og i mange andre europæiske lande endda meget højere.

Island synes således at være et skolebogseksempel på en nation, hvor kriminalitetshyppigheden er relativ lav trods industrialisering og urbanisering. Dette overrasker måske ikke kriminologer, idet det ofte er blevet bevist, at det netop er i små og kulturelt homogene samfund som Island, hvor man kan forvente en lavere kriminalitetshyppighed (Adler, 1983). Alligevel er Island langt fra at være noget kriminalitetsfrit paradis, og i øvrigt er noget sådant utopisk ifølge den kendte franske sociolog Emile Durkheim's argumentation fra slutningen af 1800tallet $(1897 ; 1933)$. Durkheim påstod at kriminalitet og straf tjente det vigtige formål at styrke sammenholdet i samfundet. Borgernes fælles misbilligelse af kriminalitet og forbryderen cementerer ifølge Durkheim grænsen for det tilladelige i samfundet, grænsen mellem det, man må og det, man ikke må. Forbrydelser og samfundets reaktion over for dem giver klar besked om, hvilke regler der gælder i samfundet, og derigennem forstærkes de lovlydiges følelse af at de er ærværdige borgere. Rollerne, som forbrydelser og straf spiller, skulle ifølge Durkheim ikke mindst have stor betydning i perioder hvor samfundet går igennem stærke ændringer. Her er de seneste årtier i Island et godt eksempel. I denne sammenhæng dukker det spørgsmål op hvilken type forbrydelser og lovovertrædelser er hyppige i det islandske samfund, for ifølge Durkheim er kriminalitet en uadskillelig del af alle samfund, skønt dens karakter og art kan være yderst forskellig.

\section{Lovovertrædelser i forbindelse med spiritusindtagelse}

Utvivlsomt husker mange det noget ejendommelige $\varnothing$ lforbud i Island, der til slut blev ophævet i 1989 (Gunnlaugsson og Galliher, 2000). Dette forbud, der stod på næsten hele det 20. århundrede, viser meget tydeligt, hvor stort et samfundsmæssigt problem befolkningens spiritusindtagelse var ifølge myndighedernes opfattelse. Bekymringer over faren gav sig udslag i mange forskellige foranstaltninger i Island. Vi kan tage nogle få eksempler som bevis. Politiets anholdelser af berusede personer i Reykjavik, en by med godt 100.000 indbyggere, har været flere tusinde om året. I perioden 1990-1994 var der f. eks. ca. 2200 anholdelser pr. år i Reykjavik på grund af beruselse på offentlig gade, ifølge politiet i Reykjaviks sagsregister (Helgi Gunnlaugsson, 1997). I perioden 1999-2001 drejede det sig stadigvæk om ca. 2000 anholdelser pr. år af samme grund. Ligeledes har antallet af anbringelser i detention på grund af beruselse været på flere tusinde i de sene- 
ste år, og i årene 1999-2001 var f. eks. ca. halvdelen af alle anbringelser i detention i Reykjavik på grund af beruselse på offentlig gade (Reykjaviks Politi, 2002).

Desuden bliver tusinder anholdt for spirituskørsel. I perioden 1974-1990 anholdte politiet gennemsnitligt ca. 2400 personer om året for spirituskørsel (Helgi Gunnlaugsson, 1997). Men ligesom med anholdelser for beruselse på offentlig gade er også antallet af anholdelser på grund af spirituskørsel dalet i de allerseneste år og var i årene 1998-2002 godt 2000 pr. år (Rigspolitiet, 2003). Dette vil sige, at ca. ét procent af Islands voksne befolkning anholdes hvert år på grund af spiritusk $\varnothing$ rsel, eller ca. 800 pr. 100.000 indbyggere. I USA ligger det sammenlignelige tal på under 400 pr. 100.000 indbyggere (Cole og Smith, 2001). De fleste af disse anholdelser finder sted om natten i weekenderne, hvor politiet fører kontrol på de største udfaldsveje fra Reykjavik centrum og tager vilkårlige stikprøver for at kontrollere om bilister er berusede (grænsen i Island ligger ved $0,5 \%$ o spiritus i blodet). Anholdes personer tre gange for denne lovovertrædelse, må de regne med fængselsstraf, og kan det nævnes her, at knap en tredjedel af fangerne i Islands fængsler i 1990 afsonede straf for overtrædelser af færdselsloven (Gunnlaugsson og Galliher, 2000). I de seneste år er denne procentdel faldet kraftigt, idet retssystemet nu tilbyder andre afstraffelsesmetoder, men procentdelen var dog stadigvæk høj i 2002, eller omtrent $20 \%$ af alle fanger i Islands fængsler (Fængselsvæsenets årsrapport, 2003).

Tallene viser meget tydeligt myndighedernes foranstaltninger mod spiritusindtagelse, og en stor del af politistyrken er tilsyneladende beskæftiget inden for dette område. Ligeledes giver tallene os et fingerpeg om, at problemerne i forbindelse med spiritusindtagelse er meget alvorlige i Island. Islændinges skikke omkring spiritus har længe været anset for at være ret simple, og antallet af personer, der søger hjælp på grund af alkoholmisbrug, er meget højt eller næsten 2000 personer, der blev indlagt til behandling for misbrug af rusmidler i 2003 (Morgunblaðið, 2004a). I stærk modstrid til dette står, at den islandske befolkning ifølge officielle statistikker over forbrug af spiritus forholdsmæssigt indtager langt mindre spiritus end næsten alle andre vestlige nationer, eller kun ca. 5 liter pr. år, omregnet til ren alkohol pr. person i 2002 (Islands Statistik, 2004). Til trods for dette făr emnet megen opmærksomhed i Island og kontrollen med befolkningens spiritusindtagelse ligeledes.

\section{Narkotika i Island}

Myndighedernes bekymringer på grund af rusmidler rettes mod mere end spiritus. Samtidigt med at øl blev tilladt i Island i 1989 sattes der øget kraft i kampen mod narkotika. Opinionsundersøgelser viser, at narkotikamisbrug af de fleste anses for at være det alvorligste problem som man slås med i Island. Undersøgelser 
viser ligeledes, at størstedelen af befolkningen mener, at roden til kriminalitet ligger i misbrug af rusmidler, hvilket tydeligt viser hvor store bekymringer man generelt har over stofmisbrug (Gunnlaugsson og Galliher, 2000). Myndighederne er af samme mening som befolkningen og har iværksat mange projekter og programmer siden man først blev opmærksom på narkotika omkring 1970. En speciel politiafdeling blev grundlagt i 1971, lige som også en selvstændig domstol, der udelukkende skulle beskæftige sig med narkotikasager og samtidigt være den officielle ledelse af den specielle politistyrke. Denne opbygning stod i modsætning til opbygningen i det islandske strafferetsvæsen, der grundlæggende er et anklageretsvæsen (jf. lov nr. 27 af 1951 og love nr. 107-9 af 1976), hvilket tydeligt viser hvor alvorligt myndighederne så på de narkotiske stoffers indtrængen $\mathrm{i}$ det islandske samfund. Denne plage måtte håndteres af specialiserede og selvstændige myndigheder hvis det ikke skulle gå galt, også selv om ordningen ikke var i overensstemmelse med de strengeste lovtraditioner (Jónatan Pórmundsson, 1980).

I 1992 blev der imidlertid foretaget gennemgribende ændringer i det islandske retsvæsen, hvorved blandt andet narkotikadomstolen blev nedlagt i overensstemmelse med de generelle retslige bestemmelser. Narkotikapolitiets specialstyrke arbejder dog videre. Dens medarbejderstab er vokset kraftigt og er nu i 2004 blevet en af de største specialstyrker inden for rigspolitichefens område med 24 aktive medarbejdere, 16 i Reykjavik og 8 spredt over hele landet. For at give en ide om tilvæksten, kan det nævnes, at der i 1984 arbejdede 7 medarbejdere i narkotikapolitiet, 14 i 1990 og ca. 20 i 1995 (Gunnlaugsson og Galliher, 2000). Antallet af ansatte i den almene politistyrke har derimod været meget mere stabilt i samme periode og var i 1998, med alle landets distrikter, ca. 650 (Rigspolitiets årsrapport, 1999).

Hyppigheden af narkotikakriminalitet er for en stor del afhængig af myndighedernes prioritering og initiativarbejde. Spørgsmålet er hvor udbredt denne kriminalitet har været og hvilken karakter den har haft. I perioden 1987-1994 anholdtes gennemsnitligt ca. 500 personer pr. år mistænkte for narkotikakriminalitet. De fleste af sagerne, eller ca. $75 \%$, drejede sig om eget forbrug, mens en mindre procentdel drejede sig om indflytning og salg af narkotika. Oplysninger om beslaglagte stoffer i perioden 1985-1995 viser, at cannabis var det langt almindeligste, og at amfetamin og kokain kun fandtes i yderst få tilfælde. Heroin har længe været nærmest ukendt i Island og kokainkrak ligeledes, som i de fleste andre lande i Europa (Gunnlaugsson og Galliher, 2000).

Hvordan har så udviklingen været gennem de seneste år, set i sammenhæng med den øgede medarbejderstab i narkotikapolitiet? I perioden 1998-2003 lå det årlige antal narkotikaforbrydelser mellem 713 og 1.371 (se tabel 1) og generelt drejede to tredjedele af sagerne sig om eget forbrug og opbevaring af narkotika 
(Rigspolitiet, 2004). Som det fremgår, er antallet af sager vokset kraftigt, og øgningen er især tydelig i 2003. Grunden til dette kan for en stor del findes i en højere prioritering af narkotikasager hos myndighederne. Det samme gør sig gældende for antallet af indsatte på grund af narkotikadomme, der er vokset kraftigt $\mathrm{i}$ de seneste år. I 1990 udgjorde narkofangerne $7 \%$ af det samlede antal fanger, i 1997 18\% og er siden vokset til over 31\% i 2002 (Statens Fængselsvæsens årsrapporter, 1991-2003). Et bemærkelsesværdigt højt antal udlændinge kommer til Island med det ene formål at fungere som narkokurérer og således bringe narkotika ind i landet. Af 25 fængslede udlændinge i 2002 sad 19 i fængslet for narkotikaforbrydelser (Morgunblaðið, 2004b).

Et $\emptyset$ get antal sager betyder altså ikke nødvendigvis et $\emptyset g e t$ narkotikamisbrug i samfundet men derimod prioritetsændringer hos de retshåndhævende myndigheder. Narkotika synes dog ifølge denne statistik at være udbredt i Island så vel som $\mathrm{i}$ andre lande.

Tabel 1. Antal og typer af narkosager hos rigspolitiet 1998-2003

\begin{tabular}{lllllll}
\hline Forbrydelsestype- & 1998 & 1999 & 2000 & 2001 & 2002 & 2003 \\
\hline-------------------------------------------- \\
Distribution/salg & 57 & 69 & 46 & 63 & 70 & 118 \\
Import & 45 & 74 & 103 & 117 & 121 & 147 \\
Privatforbrug & 493 & 693 & 507 & 593 & 632 & 934 \\
Produktion & 8 & 7 & 8 & 14 & 26 & 30 \\
Flere typer & 110 & 119 & 117 & 124 & 145 & 142 \\
I alt & $\mathbf{7 1 3}$ & $\mathbf{9 6 2}$ & $\mathbf{7 8 1}$ & $\mathbf{9 1 1}$ & $\mathbf{9 9 4}$ & $\mathbf{1 . 3 7 1}$
\end{tabular}

Oplysninger om beslaglagte stoffer viser ligeledes en stor $\emptyset$ gning fra tidligere år, men cannabis er dog stadig det langt almindeligste. Ca. $48 \mathrm{~kg}$ cannabis af forskellig art blev beslaglagt i 2001, og $60 \mathrm{~kg}$ i 2002 . Ca. $10 \mathrm{~kg}$ af amfetamin og godt $2 \mathrm{~kg}$ kokain blev beslaglagt disse to år tilsammen, og i 2002 beslaglagde politiet ca. tusind exstasy-piller (Rigspolitiet, 2004). Men hvor udbredte er egentlig narkotiske stoffer i Island?

\section{Narkotikabrug i Island set $i$ et skandinaviskt lys}

Man har foretaget en mængde undersøgelser af forbruget af alkohol og andre rusmidler i Island i de seneste år og da især blandt unge. Resultaterne af de islandske undersøgelser synes at vise, at udviklingen i forbruget af cannabisstoffer følger mønstret i andre vestlige lande, både hvad angår stigning og fald i forbruget (Gunnlaugsson og Pórisdóttir, 1999). 
Udbredelsen af cannabis blandt 15-årige synes dog at være noget større i Island end $\mathrm{i}$ andre nordiske lande, dog med undtagelse af Danmark, hvor den er størst. ESPAD-målingen i 1995 viste således, at 10\% af 15-årige i Island havde prøvet cannabis mindst én gang, 6\% af den tilsvarende aldersgruppe i Sverige og Norge, 5\% i Finland men 17\% i Danmark (Hibell et al, 1997).

Målinger blandt ældre aldersgrupper har ikke været så hyppige men viser samme mønster. I 1997 sagde ca. 20\% af 18- til 80-årige i Island at de havde prøvet cannabis mindst én gang, imod 7\% i Finland, 8\% i Norge, 11\% i Sverige men hele 30\% i Danmark. Spørges om brug af cannabis i de sidste seks måneder forud for målingen, viser det sig, at udbredelsen er omtrent den samme i alle lande, eller ca. $2 \%$, med undtagelse af Danmark, hvor 4\% indrømmer at de har prøvet stoffet. Brug af andre ulovlige narkotiske midler end cannabis synes ubetydelig ifølge målinger af denne slags i de nordiske lande (Gunnlaugsson, 1998 og Hakkarainen, 1996). I grove træk antyder disse resultater, at den ulovlige narkotikaindtagelse primært er et midlertidigt fors $\emptyset$ gs- eller socialt fænomen blandt de yngre aldersgrupper, der senere ophører med indtagelsen eller reducerer den kraftigt når de når voksenalderen. Indtagelse af stærkere stoffer som $\mathrm{f}$. eks. heroin når ikke nær så stor udbredelse og vil hovedsagelig forekomme blandt marginale grupper, der socialt og økonomisk har en svag stilling.

\section{Midler i kampen mod narkotika}

I sin kamp mod narkotika har det islandske politi anvendt forskellige utraditionelle metoder for at komme denne plage til livs f. eks. husundersøgelser, endda uden dommerkendelse, telefonaflytninger, betaling for oplysninger, konfiskering af ejendom, anvendelse af lokkedue eller endda agent provocateur (Gunnlaugsson og Galliher, 2000). Til trods for at politiets utraditionelle og hemmelige aktioner længe har været tilladt af domstolene og retfærdiggjort $\mathrm{i}$ lyset af sagens alvorlighed, må der stilles et spørgsmålstegn ved anvendelsen af sådanne metoder i en retsstat og med hensyn til privatlivets fred. Opinionsundersøgelser i Island viser dog, at et stort flertal af befolkningen går ind for anvendelsen af utraditionelle metoder i kampen mod narkotika, og det samme synes at være tilfældet i de andre nordiske lande (Gunnlaugsson og Pórisdóttir, 1999).

Vi bør alligevel her standse op og spørge os selv, om man ikke med sådanne metoder er gået for langt mod den enkeltes ret, ikke mindst når man medtager hvor udbredt brugen af narkotika er blandt unge. Sandsynligvis vil det spørgsmål blive meget nærgående inden for kriminologien og i samfundet som helhed i det 21. århundrede, hvorvidt brug og opbevaring af disse stoffer overhovedet har hjemme inden for straffeloven, eller om andre institutioner i samfundet, såsom social- og sundhedsinstitutioner ikke i stigende grad bør overtage dette emneområde. Med hensyn til de islandske myndigheders holdning til spiritus i det 20 . århundrede og forbudet imod samme er det ikke usandsynligt, at noget lignende vil ske nu over for visse narkotiske stoffer. 


\section{Kriminalitetsudviklingen i Island 1998-2003}

Som tidligere nævnt er det relativ kort tid siden man begyndte en samlet registrering af al anmeldt kriminalitet i hele Island. Med etableringen af Islands rigspolitichefembede i 1997 koordineredes registreringen fra alle islandske politienheder, hvilket unægteligt var et stort fremskridt. Myndigheden udgiver årsrapporter, der giver et godt indblik i politiets aktivitet på landsplan og en oversigt over antal og karakter af de sager som politiet beskæftiger sig med på ethvert tidspunkt. Med dette fremskridt åbnedes muligheden for at se udviklingskurver over kriminalitet i en længere periode sådan som dette kommer frem i politiets sagsregister, og samtidigt skabes et grundlag for sammenlignende undersøgelser på internationalt plan. Dog må sådanne sammenligninger altid tages med forbehold, idet politiets registreringsregler er forskellige i forskellige lande.

Overtrædelser af straffeloven udgør i Island mindre end 20\% af politiets opgaver, hvorimod overtrædelser af færdselsloven er ca. 70\% af alle opgaver. Som det fremgår af tabel 2 ændres helhedsantallet af overtrædelser af straffeloven kun ubetydeligt fra år til år, især i perioden 1999-2003. For indbrud, der hovedsagelig deles op i indbrud i biler, virksomheder og institutioner, er antallet steget, så vel som for tyverier. Tilvæksten af sager i disse kategorier har stimuleret en tendens hvor flere og flere i Island anser det for nødvendigt at anskaffe sig sikkerhedssystemer, og sikkerhedsvirksomheder har haft stor $\emptyset$ konomisk fremgang i de seneste år.

Røverier har været meget fremtrædende i debatten i Island i den seneste tid, især bankrøverier og røverier i kiosker. Massemedierne har givet disse tilfælde betydelig omtale, idet de anses for at indebære en ny trussel mod borgernes sikkerhed (Morgunblaðið, 2003c og e). Langt de fleste af disse sager er blevet opklaret af politiet. De kriminelle har som regel været unge mænd i 20-års alderen med et skarpt instrument og en elefanthue, som ikke har fået noget stort udbytte af røveriet. Røverierne har heldigvis næsten alle været udført meget uprofessionelt og efter en pludselig indskydelse. Som eksempel kan det nævnes, at en teenager, der blev anholdt umiddelbart efter episoden hvor han sad i et busstoppested uden for bankfilialen og ventede efter bussen (Morgunblaðið, 2003a). For hele kategorien røverier var hyppigheden i 2003 ca. 13 pr. 100.000 indbyggere.

Mere komplicerede berigelsesforbrydelser har ligeledes fået stor opmærksomhed på det seneste og er blevet undersøgt både hos politiet og hos konkurrencemyndighederne. Især har nyhedsdækningen omhandlet sager om ulovligt samråd mellem virksomheder om prisfiksering, og da mest på grønsagsmarkedet og inden for handel med olieprodukter. Der er i disse sager tale om meget højere beløb end i andre berigelsesforbrydelser. Domme er blevet afsagt i sagen angående grønsagsmarkedet (Morgunblaðið, 2003b), hvor de anklagede blev idømt store bøder (ialt ca. 4 millioner $\mathrm{dkr}$ ), men undersøgelser af olieselskabernes ulov- 
lige aftale, der ifølge foreløbige rapporter synes at være af meget stort omfang, er endnu ikke afsluttet.

Organiseret kriminalitet har i øvrigt ikke været særlig iøjnefaldende, bortset fra narkotikahandelen. Dog bør det nævnes, at medlemmer fra kriminelle grupper fra Danmark og Norge, Hells Angels og Banditos, har gjort forsøg på at komme til Island efter eget udsagn på udflugt i 2002 og 2003 men blev omgående udvist af landet af rigspolitiet (Morgunblaðið, 2003d). Den officielle grund til udvisningen var forebyggelse af indtrængen af internationale kriminelle organisationer.

Tabel 2. Antal og typer af sager hos rigspolitiet 1998-2003

\begin{tabular}{|c|c|c|c|c|c|c|}
\hline Forbrydelsestype & 1998 & 1999 & 2000 & 2001 & 2002 & 2003 \\
\hline Indbrud & 2.111 & 2.556 & 2.407 & 2.857 & 3.208 & 2.875 \\
\hline Tyveri & 5.445 & 6.787 & 7.439 & 7.022 & 7.378 & 6.347 \\
\hline Røveri & 19 & 40 & 34 & 39 & 32 & 39 \\
\hline $\begin{array}{l}\text { Andre berigelses- } \\
\text { forbrydelser }\end{array}$ & 528 & 657 & 602 & 604 & 712 & 715 \\
\hline Vold & 1.111 & 1.082 & 1.134 & 1.065 & 1.085 & 1.061 \\
\hline $\begin{array}{l}\text { Vold, herunder } \\
\text { legemsbeskadigelse }\end{array}$ & 263 & 258 & 297 & 324 & 185 & 178 \\
\hline Drab & 0 & 2 & 5 & 1 & 4 & 0 \\
\hline Voldtægt & 44 & 48 & 36 & 51 & 74 & 69 \\
\hline Andre seksualforbr. & $\left.\mathrm{X}_{2}\right)$ & 182 & 192 & 231 & 250 & 260 \\
\hline I alt & 9.521 & 11.612 & 12.146 & 12.194 & 12.928 & 11.544 \\
\hline
\end{tabular}

1) oplysn. 1. februar 2004

2) oplysninger mangler

Voldssager har været temmelig fremtrædende i den offentlige debat i Island i de seneste år, og mange er af den mening at samfundet i stadig stigende grad præges af vold, samtidig med at volden bliver mere og mere skånselsløs (Gunnlaugsson, 2000). Ifølge politiets oplysninger er dog antallet af voldssager stort set uændret fra år til år, og det er bemærkelsesværdigt at antallet af sager, der omhandler legemsbeskadigelser, er faldet betydeligt i denne periode.

Island synes at have oplevet et skybrud af drabssager i de seneste år, og 2000 er sikkert det mest bemærkelsesværdige år i denne henseende med $\mathrm{i}$ alt fem drab. Sammenligner man drabshyppigheden det år med tallene fra andre lande, står det relativt højt, eller på ca. 1,75 drab pr. 100.000 indbyggere. Men da Island er en lille nation med under 300.000 indbyggere, må hyppigheden betragtes over en længere periode for at udjævne de uundgåelige svingninger hvor antallet af sager 
pr. år som regel er lavt. Ser vi på hele perioden 1998-2003, viser det sig at hyppigheden af drab i Island er gennemsnitlig ca. 2 drab pr. år, eller ca. 0,7 drab pr. år pr. 100.000 indbyggere, hvilket er blandt de laveste tal der ses i sammenligningen blandt vestlige nationer.

Antallet af seksualforbrydelser er steget betydeligt i denne periode, og dette gælder de fleste typer forbrydelser inden for kategorien. Den største stigning var i anmeldelser på grund af seksuelt misbrug af børn yngre end 14 år og anmeldelser af incest. Antallet af anklager for voldtægt er også steget, som det ses i tabel 2. Ifølge de foreliggende oplysninger var hyppigheden af anmeldte tilfælde af voldtægt i Island ca. 23 pr. 100.000 indbyggere i 2003. I andre kategorier så som opbevaring af børnepornografi og seksuelt overgreb over for mentalt handicappede eller over for bevidstløs person ses ligeledes en stigning i antallet. Hvorvidt det her drejer sig om en faktisk stigning i samfundet eller stærkere sandsynlighed for at sådanne tilfælde anmeldes i dag er vanskeligt at sige med sikkerhed. Mediernes behandling af seksualforbrydelser og de lidelser, som ofrene udsættes for, har dog været fremtrædende i den seneste tid, og det er tænkeligt at ofre nu i mindre grad tøver før de træder frem og anmelder et tilfælde. Oplysninger fra kvinderådgivningscentret Stigamot, Kvindernes Forbund mod seksuel vold og fra Landshospitalets skadestue for voldtægter og andre seksualforbrydelser viser dog, at mange ofre stadig vægrer sig ved at anmelde forbrydelserne til politiet.

I helhed viser tallene fra rigspolitichefen, at antallet af sager ændres meget lidt fra år til år. Visse udsving ses i de forskellige kategorier inden for overtrædelser af straffeloven, men ingen specielle udviklinger tyder på at antallet af forbrydelser er steget abnormt i de seneste år. To kategorier skiller sig dog ud fra resten. Narkotikakriminaliteten er steget kraftigt, ligesom også kategorien seksuelle forbrydelser. Hvad angår narkotika synes her primært at være tale om myndighedernes øgede vægt på at standse lovovertrædelser af denne art. Det er derimod vanskeligere at give nogen grund for øgningen af seksuelle forbrydelser. Det er dog ikke usandsynligt at den afgørende faktor her nærmere er seksualofrenes $\emptyset$ gede tendens til at anmelde end en faktisk øgning af seksuelle forbrydelser. Dette bør dog undersøges nærmere.

\section{Voksende bekymringer over kriminalitet i Island}

Som var tidligere nævnt er det relativ kort tid siden en systematisk registrering af officielle oplysninger om kriminalitet blev påbegyndt i Island. Kriminologer har derfor anvendt andre metoder for at opnå en bedre forståelse af emnet kriminalitet end den, man får fra officielle tal. Målinger af den islandske befolknings holdning til kriminalitet viser en voksende bekymring over fænomenet. Den seneste holdningsmåling blev foretaget i 2002, hvor knap en fjerdedel af befolkningen anså kriminalitet for at være et meget stort problem, sammenlignet med 
12\% i 1989 (Gunnlaugsson, 2003). Bekymringerne synes dog at have været størst i 1997, da over $40 \%$ af den islandske befolkning mente at kriminalitet var et meget stort problem. Et stort flertal i alle målingerne anser straffene for at være for milde, og denne vurdering følger samme udsving som vurderingen af forbrydelsers alvorlighed. Når bekymringerne over kriminalitet er størst, mener de fleste samtidigt at straffene er alt for milde.

Til trods for $\emptyset$ gede bekymringer over kriminalitet er der dog sket relativt få ændringer af indbyggernes tryghedsfølelse i samme periode. De fleste indbyggere i Island føler sig trygge ved at gå alene om natten i deres egen kvarter, og tryghedsfølelsen er størst hos beboere uden for hovedstadsområdet. Dette resultat antyder, at der bør skelnes mellem offentlighedens generelle holdning over for kriminalitet og beboernes personlige frygt for kriminalitet. Generelle bekymringer over kriminalitet i samfundet stikker således ikke nødvendigvis så dybt at de har indflydelse på den enkeltes tryghedsfornemmelse $\mathrm{i}$ vedkommendes egen hjemby eller hjemegn. Det fremgår heller ikke at ændringer på indbyggernes holdning til kriminalitet genspejler udviklingen inden for politiet hvad angår dette emne. Andre faktorer synes dér at spille stærkere roller. Dog viste en unders $\varnothing$ gelse i 2001 at massemediernes negative behandling af Reykjaviks centrum tilsyneladende havde en midlertidig indflydelse på Reykjavik-boeres tryghedsfornemmelse ved at færdes i centrum om natten (Gunnlaugsson og Pórisdóttir, 2003).

\section{Slutningsord}

Men hvorfor har man i Island bekymringer over kriminalitet? Der kan være flere forklaringer. Mediernes dækning af den øgede vold af forskellig art og unges øgede narkotikamisbrug har uden tvivl skabt bekymringer hos befolkningen. Det er ikke usandsynligt at specifikke kriminelle sager, der er forekommet i løbet af de seneste år og har vakt frygt og omtale, vil sætte sit spor på befolkningens holdning til kriminalitet. Private massemedier er blevet mere fremtrædende i Island i de seneste år, ikke mindst radio og TV, og kriminalitet er populært nyhedsstof i Island som i andre lande. Kriminelle emner er derfor nu i videre udstrækning på programmet i den generelle offentlige debat end tidligere, samtidig med at retshåndhæverne er blevet mere specialiserede og oplysninger om kriminalitet lettere tilgængelige. Skønt hyppigheden af forbrydelser generelt ikke er steget betydeligt i de seneste år i Island, viser kriminologers undersøgelser (Maguire og Pastore, 1985) at en stadig voksende del af befolkningen er af den opfattelse at kriminalitet og vold er et voksende problem. Det er her bemærkelsesværdigt, at disse generelle bekymringer over kriminalitet i landet ikke har haft indflydelse på borgernes vurdering af egen tryghed ved at færdes om natten i deres hjemby. 
Det må anses for vigtigt at debatten om kriminalitet og problemerne, som den skaber, er overvejet og realistisk. Man kan ikke gå ud fra, at massemedier på det private marked eller politikere på eget initiativ praktiserer en overvejet og saglig debat om politikken omkring emneområdet kriminalitet. Dette krav må nødvendigvis hvile tungest på retshåndhævelsessystemets parter, og da ikke mindst de personer, der beskæftiger sig med undersøgelser i dette emneområde.

\section{LITTERATUR}

Adler, F. (1983). Nations Not Obsessed with Crime. Littleton, Colo.: Fred B. Rothman and Company. Cole, G. F. og C. E. Smith, (2001). The American System of Criminal Justice System. Ninth Edition. Wadsworth.

Durkheim, E. (1897, 1933). The Division of Labor in Society. New York: The Free Press.

Gunnlaugsson, H. (1996). "Empiri og ideologi i kriminologi: Den objektive og subjektive siden av kriminaliteten i Island". Nordisk Tidsskrift for Kriminalvidenskab. Marts, 83, nr. 1: 14-26.

Gunnlaugsson, H. (1997). "Kriminaliteten i Island: Internasjonalt perspektiv". Nordisk Tidsskrift for Kriminalvidenskab. Februar, 84, nr. 1: 50-59.

Gunnlaugsson, H. (1998). ”Narkotikabruk, attityder och kontollpolitik i Island: En jamförelse med det övriga Norden”. Nordisk Alkohol- \& narkotikatidskrift. Vol. 15, nr. 5 og 6: 278-287. Helsinki.

Gunnlaugsson, H. (2000). "Kriminalitet og straffepolitik i Island". Nordisk Tidsskrift for Kriminalvidenskab. Februar, 87, nr. 1: 38-47.

Gunnlaugsson, H. (2003). Viðhorf Íslendinga til afbrota 1989-2002 (Islændingenes holdning til brott i 1989-2002). I Rannsóknir i félagsvísindum IV. F.H. Jónsson (red), s. 105-115. Háskólaútgáfan og Félagsvísindastofnun Háskóla Íslands.

Gunnlaugsson, H. og J. F. Galliher, (2000). Wayward Icelanders: Punishment, Boundary Maintenance and the Creation of Crime. Madison: University of Wisconsin Press.

Gunnlaugsson, H. og R. Pórisdóttir (1999). "Iceland and the Nordic Drug Survey: Drug use, public attitudes and youth". YOUNG. Vol. 7, nr. 1: 19-35.

Gunnlaugsson, H. og R. Pórisdóttir (2003). Nyhedsformidling og frygt for kriminalitet i Reykjavik: Ændring i tryghed i 2001. Nordisk Tidsskrift for Kriminalvidenskab. Juni, 90, nr. 2: 105-112.

Hakkarainen, P., L. Laursen, C. Tigerstedt (red.) (1996). Discussing drugs and control policy: Comparative studies on four Nordic countries. NAD Publication no. 31. Nordic Council for Alcohol and Drug Research (NAD). Helsinki.

Hibell, B., B. Anderson, P. Bjarnason, A. Kokkevi, M. Morgan og A. Narusk (1997). The 1995 ESPAD report: Alcohol and other drug use among students in 26 european countries. Stockholm: Can.

Islands Statistik, (2004). Oplysninger fra hjemsidan www.hagstofan.is 20. februar 2004.

Islandske statsministerium, (1996). Skýrsla um fikniefna- og afbrotamálefni (Rapport om narko- og brottsager). Reykjavík: Det islandske statsministerium.

Morgunblaðið, (2003a). "Handtekinn eftir gripdeild í banka" (Anholdt efter et tyveri i en bank). 30. august 2003.

Morgunblaðið, (2003b). "Hæstiréttur staðfestir að grænmetisfyrirtæki höfou ólöglegt samráð” (Højesteret bekræfter at grønsagsvirksomheder havde ulovligt samråd). 30. oktober 2003.

Morgunblaðið, (2003c). "Tveir handteknir vegna ránstilraunar" (To anholdt efter forsøg på røveri). 6. desember 2003.

Morgunblaðið, (2003d). "Fimm norskum Vítisenglum vísað úr landi” (Fem norske Hells Angels udvist). 6. desember 2003.

Morgunblaðið, (2003e). "Alvarlegasta málið í ránshrinu sem á sér ekki fordæmi hérlendis" (Det alvorligste tilfælde i en series af røverier uden fortilfælde her i landet). 10. desember 2003. 
Morgunblaðið, (2004a). ”Innlögnum á Vog fjölgaði um 300 á síðasta ári” (Indlæggelser på alkoholbehandlingscentret Vogur øgedes med 300 sidste år). 19. februar 2004.

Morgunblaðið, (2004b). "115 útlendingar afplánuðu dóma hér á landi 1996-2003: Sex af hverjum tíu sátu inni vegna fíkniefnabrota" (115 udlændinge afsonede straffe i Island i perioden 1996-2003:

Seks ud af ti sad fængslet p. gr. a. narkotikaforbrydelser). 22. februar 2004.

Reykjaviks Politimester (2002). Arsrapport 2001. Reykjavik: Politimesteren.

Rigspolitiet (2004). Arsrapporter 1999-2003. Reykjavik: Rigspolitiet.

Statens Fængselsvæsens årsrapporter, (1991-2003). Arsrapporter. Reykjavík: Statens Fængselsvæsen.

Maguire, K. og A. Pastore, A. (1995). Sourcebook of Criminal Justice Statistics. U.S. Department of Justice, Bureau of Justice Statistics.

Pórmundsson, J. (1980). Opinbert réttarfar (Offentlige kriminalsager). 2. hæfte, 2. udgave. Reykjavík.

Adresse:

Islands Universitet

Det sociologiske fakultet

101 Reykjavik

Island

E-post: helgigun@hi.is 